\title{
Cognitive processes, rewards and online knowledge sharing behaviour: The moderating effect of organisational innovation
}

\begin{abstract}
Purpose - Online knowledge sharing is a critical process for maintaining organisational competitive advantage. This research develops a new conceptual framework that investigates the moderating impacts of innovation on self-efficacy, extrinsic and intrinsic rewards on employees' online knowledge sharing behaviour in public and private sector companies.

Design/methodology/approach - This research analysed 200 responses to test the moderating effects of organisational innovation on the relationship between self-efficacy and rewards and online knowledge sharing behviours. Analysing using component-based partial least squares (PLS) approach and Smart-PLS 3 software.

Findings - Our results reveal that self-efficacy significantly affects online knowledge sharing behaviour in firms, regardless of the organisation type. Extrinsic rewards encourage employees in private companies to share knowledge online, whereas intrinsic rewards work effectively in public companies. Additionally, the study found the moderating role of organisational innovation in examining the relationship between rewards and online knowledge sharing behaviour.
\end{abstract}

Research limitations/implications - Future research may consider different dimensions such as knowledge donating and collecting behaviours as well as motives, such as self-enjoyment, reciprocity or social interaction ties may be investigated to get a deeper understanding of online knowledge sharing behaviour.

Practical implications - Firms must tailor training and rewards to suit employees' ability and needs so as to align with organisational type and innovation.

Originality/Value - The study's distinctive contribution is the under-researched context of Vietnamese public and private sector banks for investigating the moderating effects of organisational innovation on micro- and meso-factors on online knowledge sharing behaviour.

Keywords: Extrinsic rewards; Intrinsic Rewards; Online knowledge sharing; Public companies; Private companies

Paper type: Research paper 


\section{Introduction}

Prior research has examined knowledge self-efficacy and rewards as crucial determinants of knowledge sharing that then affect organisational innovation (Nguyen, 2020b; Nguyen et al., 2019c). In modern times, knowledge is regarded as key to sustainable competitive advantage and the ability of organsiatons to apply knowledge to its productive processes is viewed as a key factor in an organisation's value creation and realisation processes (Malik et al.,, 2018) as well as leading to a range of innovation outcomes (Bock and Kim, 2002; Bock et al., 2005; Nguyen, 2020b; Malik and Nilakant, 2016; Malik et al., 2020). However, as valuable knowledge often resides in an employee's mind (Nguyen et al., 2019c), transfer of knowledge in an organisation ultimately depends on employees' knowledge sharing behaviours (Bock et al., 2005; Nguyen, 2020a). When knowledge is not shared among employees, knowledge gap increases, leading to low productivity (Baird and Henderson, 2001).

In order to enhance knowledge sharing behaviour of employees, many organisations have set up online knowledge sharing systems to facilitate the knowledge sharing process. However, in an organisation, employees may be reluctant to share their valuable and essential knowledge (Bock and Kim, 2002; Davenport and Prusak, 1997; Nguyen et al., 2019a; Nguyen et al., 2019b). Consequently, employees tend to hoard knowledge and look suspiciously upon knowledge shared by others (Bock and Kim, 2002). This natural tendency is not easy to change. Ruggles (1998) examined 431 U.S. and European organisations and argued that the most significant difficulty in knowledge management is changing an individual's behaviour. The annual losses associated with knowledge hiding may cost the average American company up to US\$ 47 million in productivity losses (Panopto, 2018). It is, thus, imperative for to understand what motivates employees to share knowledge in an online mode and transfer that knowledge to a firm's capital to contribute to the development of an organisation's competitive advantage.

In an attempt to develop a clearer understanding of the motivators of knowledge sharing, prior researchers have indicated several factors that motivate employees to share knowledge. For instance, knowledge self-efficacy and rewards were shown to significantly affect knowledge sharing (Lin, 2007a; Bock and Kim, 2002; Nguyen et al., 2019c). However, despite the emphasis on motivational factors when examining online knowledge sharing, there are several limitations in the existing literature. 
First, although rewards vary from extrinsic incentives such as bonuses or promotions to intrinsic rewards such as praise and public recognition, majority of prior studies have tended to focused on extrinsic rewards. This may stem from the relative ease and measurement of acquisition of extrinsic rather than intrinsic rewards (Choi et al., 2008; Bartol and Srivastava, 2002; Wasko and Faraj, 2005). However, extrinsic rewards per se are not sufficient to motivative online knowledge sharing behaviour. Thus, some researchers have argued that intrinsic rewards are even more important than extrinsic rewards in eliciting knowledge sharing behviours (Bartol and Srivastava, 2002; Choi et al., 2008). The research on the impact of rewards is equivocal. For example, Kim and Lee (2006), Hau et al. (2013), Taylor (2006) and Choi et al. (2008) reinforce the belief that rewards positively affect knowledge sharing behaviour, but other studies have reported no effect and a negative impact, such as those by Bock and Kim (2002), Bock et al. (2005), and Olatokun and Nwafor (2012). These results necessitate the need to find the potential causes for such inconsistencies.

Another limitation in existing research is that when examining motivators of online knowledge sharing, previous scholars have revealed little about how the impacts of motivators differ between public and private companies. Public and private companies differ widely in their motivation, values and purpose that employees bring to work, due to the differences in management purpose and objectives, the key job types and organisational structures (Malik, 2018). Public companies, for example, operate in a more bureaucratic manner and are directed to serve the society and citizens and its employees exhibit altruistic values (Yeh et al., 2018). In contrast, private companies are profit-oriented and face fierce competition and are faced with a rapidly changing market environment (Yeh et al., 2018). Thus, these differences between public and private companies may lead to different driving forces of employees' online knowledge sharing behaviours.

Finally, organisational innovation has not been examined as a moderator in knowledge sharing. Organisational innovation is a critical factor for both public and private enterprises' achievement of goals, and as such, has received a great deal of attention from researchers and practitioners to understand the impact of knowledge sharing on organisational innovation (Calantone and Stanko, 2007; Khedhaouria and Jamal, 2015; Lin, 2007b; Tangaraja et al., 2015). Further, researchers and practitioners have to consider how to design their reward systems for fostering organisational innovation. Active sharing knowledge is known to enhance organisational innovation because personal knowledge could be transferred to organisational capital, which can enhance employee performance and reduce redundant learning time 
(Calantone et al., 2002; Scarbrough, 2003). Conversely, in highly innovative companies, employees tend to have more responsibilities to contribute to the innovativeness of their company, and as a result, the forces that drive knowledge sharing are likely to be different in these firms.

In line of the above equivocal findings and tensions in the liteature, the objective of this study is threefold: (1) to deepen the understanding of the drivers of online knowledge sharing in an organisation, wherein both extrinsic and intrinsic rewards are simultaneously examined; (2) to examine the driving factors of online knowledge sharing in public and private companies, and (3) to investigate the moderating role of organisational innovation in online knowledge sharing. To this end, we contribute by developing a conceptual model for analysing the above relationships. The rest of the paper is organised as follows. First, the paper presents a detailed literature review, followed by the study's hypotheses and the methodological approach adopted. This is followed by the results and discussion sections, respectively. Next, implications for theory and practice are discussed followed by conclusion .

\section{Literature review}

\section{Online knowledge sharing in organisations}

In this research, we define online knowledge sharing as the process by which employees transfer or disseminate their opinions, experience, skills and know-how via online means to other colleagues within the organisation to provide them mutual help in problem-solving and ideas development (Nguyen, 2020a; Van den Hooff et al., 2012; Nguyen et al., 2019a). Online knowledge sharing is considered a crucial part of building a knowledge-based competitive advantage in an organisation (Kogut and Zander, 1992; Argote and Ingram, 2000; Cohen and Levinthal, 1990). Online knowledge sharing often enhances interpersonal socialisation in an organisation as they facilitate a continuous series of interaction that facilitate the creation and transfer of knowledge. A number of organisations have recognised the importance of the online transfer of knowledge in improving the performance of employees. Therefore, such organisations have invested in technological infrastructure that facilitates online knowledge sharing (Bughin and Manyika, 2007; Young et al., 2008).

According to motivation theory, individuals need to have motivation to perform a behaviour. In the organisational online knowledge sharing context, motivation may stem from employees' knowledge self-efficacy when employees are confident about their knowledge to 
contribute to the organisation. Kumar et al. (2009) argue that employees with higher levels of self-efficacy often display considerably flexible behaviour such as giving useful advice that benefits the organisation but not mandated in the contract. They tend to view knowledge sharing as one important component of their work and believe that sharing knowledge is very important to effective daily work and entails getting along with others in pleasant (Borges, 2013; Wang and Yang, 2007).

Motivation to share knowledge online in an organisation may also originate from the rewards that are offered by the organisation. Vroom's (1964) expectancy theory indicates that motivation level to perform a behaviour relates directly with rewards, which produce fulfilment (Kiatkawsin and Han, 2017; Purvis et al., 2015). Thus, extrinsic and intrinsic rewards are often proposed to encourage employees to contribute to the organisation including actively participating in online knowledge sharing. Employees often weigh their expectations of rewards against costs if they share their knowledge online (Taylor, 2006). An effective reward system will encourage employees to increase effort, which can potentially lead to performance improvement. The combination of extrinsic and intrinsic rewards may be helpful in encouraging employee's online knowledge sharing. Although a variety of studies have investigated rewards, but there is a paucity of research which includes both types of reward in a single study. Table 1 shows previous studies examining rewards in organisations in the knowledge sharing literature.

\section{Public versus Private Sector Organisations}

The nature and extent of differences between employees in public and private companies have been a topic of debate. This debate stems from different aspects that public and private sector organisations depict (Milner, 2000). The first aspect is organisational goals. In public organisations, it is more difficult to measure organisational goals because they may be conflicting and be significantly influenced by political issues (Pandey and Wright, 2006). The second aspect is the diversity of goals and ownership in public organisations as they vary in terms of their ownership, funding, and control (Willem and Buelens, 2007). Fragmented authority and less incentive for efficiency are other aspects that differentiate public from private sector organisations (Heffron, 1989). The differences between public and private organisations may lead to different determinants of online knowledge sharing behaviour of employees. Previous studies have shown that there are differences in terms of the motivators of knowledge sharing between public and private sector organisations. For example, Liebowitz and Yan 
(2004) argued that in public sector organisations, knowledge sharing hardly occurred because employees often consider knowledge as power and useful for promotion opportunities. Seba $e t$ al. (2012a) found that organisational structure, leadership, time allocation, and trust may impede knowledge sharing in the public sector, such as that seen in the Dubai police force. Lin (2007a) found the antecedents of employee's knowledge sharing attitudes and intentions in 50 private sector organisations were reciprocal benefits, knowledge self-efficacy, and enjoyment in helping others. However, in the literature on knowledge sharing, few studies have compared the influence of drivers of online knowledge sharing in different organisational types, such as in the public and private sectors.

\section{Knowledge sharing motives}

Knowledge self-efficacy is defined as the employees' confidence in their ability to provide valuable knowledge to other colleagues in an organisation (Kankanhalli et al., 2005b; Spreitzer, 1995). Based on the self-efficacy theory (Bandura and Walters, 1977), employees, who have high levels of knowledge self-efficacy, tend to have powerful self-motivation (Hsu et al., 2007), which often leads to active knowledge sharing (Lin, 2007a; Bock and Kim, 2002).

\section{Hypotheses Development}

Employees who have a high level of knowledge self-efficacy, tend to share knowledge online with colleagues (Kankanhalli et al., 2005b; Wasko and Faraj, 2005; Bock and Kim, 2002). Malik, Boyle and Mitchell, 2017; Olatokun and Nwafor (2012), who examined 297 employees across six ministries in the Nigerian civil service commission, found that competence and confidence, which refer to knowledge self-efficacy, may be a requirement if an employee wishes to engage in online knowledge sharing in a public company. Amayah (2013) argued that the key factors affecting knowledge sharing in public companies, such as knowledge selfefficacy, could also be successfully used in private companies. Therefore, we propose the following hypothesis:

H1: Knowledge self-efficacy is positively related to online knowledge sharing behaviour in a) public companies and b) private companies. 
Table 1: Studies Examining Self-efficacy \& Organisational Rewards in Knowledge Sharing Literature

\begin{tabular}{|c|c|c|c|c|c|c|c|c|c|}
\hline \multirow[b]{2}{*}{$\begin{array}{l}\text { Study's } \\
\text { Authors }\end{array}$} & \multirow{2}{*}{$\underset{\text { In }}{\text { organizations }}$} & \multirow[b]{2}{*}{$\begin{array}{l}\text { Organisation } \\
\text { type }\end{array}$} & \multirow{2}{*}{$\begin{array}{c}\text { Online } \\
\text { knowledge } \\
\text { sharing }\end{array}$} & \multirow[b]{2}{*}{$\begin{array}{l}\text { Knowledge } \\
\text { self-efficacy }\end{array}$} & \multicolumn{2}{|c|}{ Rewards } & \multirow[b]{2}{*}{ Country } & \multirow[b]{2}{*}{$\begin{array}{l}\text { Sample } \\
\text { size }\end{array}$} & \multirow[b]{2}{*}{ Sample characteristics } \\
\hline & & & & & $\begin{array}{l}\text { General } \\
\text { rewards }\end{array}$ & $\begin{array}{l}\text { Specific } \\
\text { rewards }\end{array}$ & & & \\
\hline $\begin{array}{l}\text { Al-Alawi et } \\
\text { al. (2007) }\end{array}$ & $\sqrt{ }$ & $\begin{array}{l}\text { Both public } \\
\text { and private }\end{array}$ & & & $\sqrt{ }$ & & Bahrain & 231 & $\begin{array}{l}\text { employees in organisations from } \\
\text { the public and private sectors in } \\
\text { the Kingdom of Bahrain }\end{array}$ \\
\hline $\begin{array}{l}\text { Al-Busaidi } \\
\text { et al. }(2010)\end{array}$ & $\checkmark$ & Private & $\checkmark$ & & $\checkmark$ & & Oman & 104 & $\begin{array}{l}\text { employees in a major private } \\
\text { petroleum organisation }\end{array}$ \\
\hline $\begin{array}{l}\text { Alam et al. } \\
(2009)\end{array}$ & $\sqrt{ }$ & NA & & & $\sqrt{ }$ & & Malaysia & 305 & $\begin{array}{l}\text { employees in manufacturing } \\
\text { companies from Melaka and } \\
\text { Johor states }\end{array}$ \\
\hline $\begin{array}{l}\text { Bock et al. } \\
(2005)\end{array}$ & $\sqrt{ }$ & NA & & & & Extrinsic & Korea & 154 & $\begin{array}{l}\text { employees from } 27 \\
\text { organisations }\end{array}$ \\
\hline $\begin{array}{l}\text { Bock and } \\
\text { Kim (2002) }\end{array}$ & $\checkmark$ & Public & & & & Extrinsic & Korea & 467 & $\begin{array}{l}\text { employees from four large, } \\
\text { public companies }\end{array}$ \\
\hline $\begin{array}{l}\text { Amayah } \\
(2013)\end{array}$ & $\checkmark$ & Public & & & $\sqrt{ }$ & & USA & 439 & $\begin{array}{l}\text { civil service employees at a } \\
\text { mid-size public academic } \\
\text { institution in the Midwest }\end{array}$ \\
\hline $\begin{array}{l}\text { Cho et al. } \\
(2007)\end{array}$ & $\checkmark$ & NA & & & & Extrinsic & Korea & 207 & $\begin{array}{l}\text { working adults taking evening } \\
\text { classes in the part-time MBA } \\
\text { programs of Hanyang } \\
\text { University }\end{array}$ \\
\hline $\begin{array}{l}\text { Choi et al. } \\
(2008)\end{array}$ & $\sqrt{ }$ & NA & $\sqrt{ }$ & & & $\begin{array}{l}\text { Extrinsic } \\
\text { \& intrinsic }\end{array}$ & Korea & 164 & $\begin{array}{l}\text { employees in two } \\
\text { manufacturing companies }\end{array}$ \\
\hline $\begin{array}{l}\text { Dong et al. } \\
(2010)\end{array}$ & $\sqrt{ }$ & NA & & $\sqrt{ }$ & & Extrinsic & Vietnam & 124 & $\begin{array}{l}\text { employees in six multinational } \\
\text { companies in Ho Chi Minh city. }\end{array}$ \\
\hline $\begin{array}{l}\text { Durmusoglu } \\
\text { et al. }(2014)\end{array}$ & $\checkmark$ & NA & & & $\sqrt{ }$ & & Europe & 1108 & $\begin{array}{l}\text { employees in diversified } \\
\text { European corporation active in } \\
10 \text { industries with } 11 \text { SBUs in } 9 \\
\text { different countries, e.g. Italy, } \\
\text { Russia, Turkey, UK, and others. }\end{array}$ \\
\hline $\begin{array}{l}\text { Eze et al. } \\
(2013)\end{array}$ & $\checkmark$ & NA & & & $\checkmark$ & & Malaysia & 250 & $\begin{array}{l}\text { manufacturing sector } \\
\text { participants from the SME } \\
\text { Corporation Malaysia business } \\
\text { directory }\end{array}$ \\
\hline
\end{tabular}




\begin{tabular}{|c|c|c|c|c|c|c|c|c|c|}
\hline $\begin{array}{l}\text { Fathi et al. } \\
\text { (2011) }\end{array}$ & $\checkmark$ & NA & & & $\checkmark$ & & Malaysia & 141 & $\begin{array}{l}\text { employees in a manufacturing } \\
\text { company }\end{array}$ \\
\hline $\begin{array}{l}\text { Gebreegziab } \\
\text { her (2014) }\end{array}$ & $\checkmark$ & NA & $\checkmark$ & & $\checkmark$ & & Ethiopia & 103 & $\begin{array}{l}\text { employees working for three } \\
\text { centres, namely Nile SEC, } \\
\text { ENTRO, and NELSAP-CU as } \\
\text { permanent staff and reachable } \\
\text { NBI stake holders }\end{array}$ \\
\hline $\begin{array}{l}\text { Hau et al. } \\
(2013)\end{array}$ & $\sqrt{ }$ & NA & & & & Extrinsic & Korea & 2010 & employees in multiple industries \\
\hline $\begin{array}{l}\text { Huang et al. } \\
\text { (2008) }\end{array}$ & $\checkmark$ & NA & & $\checkmark$ & & Extrinsic & China & 159 & $\begin{array}{l}\text { MBA students working in a } \\
\text { university of different } \\
\text { organisations }\end{array}$ \\
\hline $\begin{array}{l}\text { Hung et al. } \\
\text { (2011) }\end{array}$ & & NA & & & & Extrinsic & Taiwan & 120 & $\begin{array}{l}\text { upper division undergraduate } \\
\text { and MBA students from one } \\
\text { university }\end{array}$ \\
\hline $\begin{array}{l}\text { Kim and Lee } \\
(2006)\end{array}$ & $\checkmark$ & $\begin{array}{l}\text { Both public } \\
\text { and private }\end{array}$ & & & $\checkmark$ & & Korea & 322 & $\begin{array}{l}\text { employees in five public-sector } \\
\text { and five private-sector } \\
\text { organisations }\end{array}$ \\
\hline $\begin{array}{l}\text { Kumar and } \\
\text { Rose (2012) }\end{array}$ & $\checkmark$ & Public & & $\sqrt{ }$ & & Extrinsic & Malaysia & 472 & $\begin{array}{l}\text { Administrative and Diplomatic } \\
\text { Service employees from the } \\
\text { Malaysian public sector } \\
\text { organisations }\end{array}$ \\
\hline Liao (2008) & $\checkmark$ & NA & & & & Extrinsic & Taiwan & 105 & R\&D employees \\
\hline $\operatorname{Lin}(2007 b)$ & $\checkmark$ & NA & & $\checkmark$ & & Extrinsic & Taiwan & 172 & $\begin{array}{l}\text { employees from } 50 \text { large } \\
\text { organisations }\end{array}$ \\
\hline $\operatorname{Lin}(2007 a)$ & $\checkmark$ & NA & & $\sqrt{ }$ & & Extrinsic & Taiwan & 172 & $\begin{array}{l}\text { employees from } 50 \text { large } \\
\text { organisations }\end{array}$ \\
\hline $\begin{array}{l}\text { Lin et al. } \\
\text { (2009) }\end{array}$ & $\checkmark$ & NA & & $\checkmark$ & & Extrinsic & Taiwan & 172 & $\begin{array}{l}\text { employees from } 50 \text { large } \\
\text { organisations }\end{array}$ \\
\hline $\begin{array}{l}\text { Lin and Lo } \\
(2015)\end{array}$ & $\checkmark$ & NA & & & & Extrinsic & Taiwan & 180 & $\begin{array}{l}\text { nurses in a regional teaching } \\
\text { hospital }\end{array}$ \\
\hline $\begin{array}{l}\text { Olatokun } \\
\text { and Nwafor } \\
(2012)\end{array}$ & $\checkmark$ & Public & & $\sqrt{ }$ & & Extrinsic & Nigeria & 297 & $\begin{array}{l}\text { respondents across six } \\
\text { ministries in the state's Civil } \\
\text { Service Commission }\end{array}$ \\
\hline $\begin{array}{l}\text { Pee } \text { et al. } \\
\text { (2010) }\end{array}$ & $\checkmark$ & $\begin{array}{l}\text { Private } \\
\text { Public }\end{array}$ & & & $\checkmark$ & & Japan & 95 & $\begin{array}{l}\text { a dyad of business subgroup and } \\
\text { external IT consultant subgroup } \\
\text { in a project team in a particular } \\
\text { phase }\end{array}$ \\
\hline
\end{tabular}




\begin{tabular}{|c|c|c|c|c|c|c|c|c|}
\hline $\begin{array}{l}\text { Seba et al. } \\
(2012 b)\end{array}$ & $\checkmark$ & NA & & & Extrinsic & UAE & 311 & officers in Dubai Police Force \\
\hline Tan (2016) & $\checkmark$ & NA & & $\checkmark$ & Extrinsic & Malaysia & 421 & $\begin{array}{l}94 \text { professors, } 154 \text { associate } \\
\text { professors, and } 173 \text { senior } \\
\text { lecturers }\end{array}$ \\
\hline $\begin{array}{l}\text { Taylor } \\
\text { (2006) }\end{array}$ & & NA & $\checkmark$ & & Extrinsic & USA & 52 & $\begin{array}{l}\text { graduate and undergraduate } \\
\text { accounting information students } \\
\text { assigned to six groups }\end{array}$ \\
\hline $\begin{array}{l}\text { Tohidinia } \\
\text { and } \\
\text { Mosakhani } \\
(2010)\end{array}$ & $\checkmark$ & NA & $\checkmark$ & $\checkmark$ & Extrinsic & Iran & 502 & employees from oil companies \\
\hline $\begin{array}{l}\text { Wickramasi } \\
\text { nghe and } \\
\text { Widyaratne } \\
(2012)\end{array}$ & $\sqrt{ }$ & NA & $\checkmark$ & & Extrinsic & Sri Lanka & 150 & software developers \\
\hline $\begin{array}{l}\text { Wu and Zhu } \\
\text { (2012) }\end{array}$ & $\sqrt{ }$ & NA & & & Extrinsic & China & 180 & employees from ten companies \\
\hline $\begin{array}{l}\text { Zhang et al. } \\
\text { (2014) }\end{array}$ & & NA & $\checkmark$ & & Extrinsic & $\begin{array}{l}\text { Hong Kong, } \\
\text { China and } \\
\text { Netherland }\end{array}$ & 113 & $\begin{array}{l}\text { postgraduate students in } \\
\text { engineering and business in the } \\
\text { innovative virtual class }\end{array}$ \\
\hline $\begin{array}{l}\text { Zhang et al. } \\
\text { (2013) }\end{array}$ & $\checkmark$ & NA & $\checkmark$ & & Extrinsic & China & 159 & $\begin{array}{l}\text { Liaisons between employees } \\
\text { from different departments of } \\
\text { Xuan Cheng Division }\end{array}$ \\
\hline
\end{tabular}

Note: * Under rewards, general rewards refers to papers that did not specify whether the nature of rewards was extrinsic or intrinsic, whereas specified rewards refers to papers that did specify the nature of rewards as extrinsic, extrinsic or both. NA: Not available 


\section{Hypotheses development}

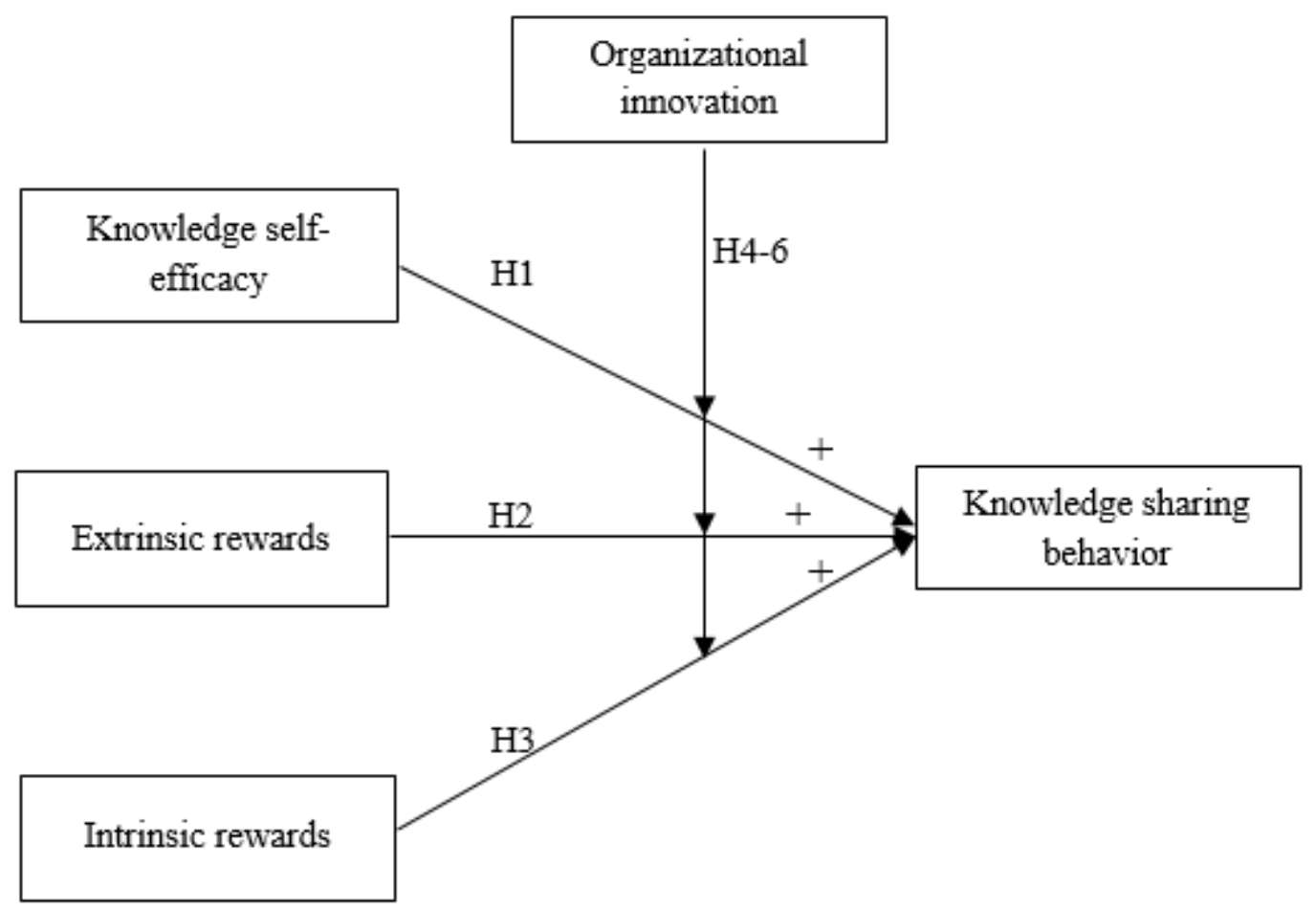

Figure 1: Conceptual framework

Figure 1 shows the study's conceptual framework.

Rewards refer to a benefit that employees can receive if they share knowledge online. Rewards can be broadly categorised into two types: extrinsic and intrinsic (Choi et al., 2008). The former refers to monetary incentives such as bonuses, paid vacations, and promotions, (Kankanhalli et al., 2005a), whereas, the latter refers to intrinsic incentives such as praise and public recognition (Choi et al., 2008). Employees often seek a strong incentive to share their knowledge online (Ryan and Deci, 2000; Roca and Gagné, 2008). It is unrealistic to assume that an employee will be willing to share their valuable knowledge without taking into an assessment what may be gained and lost through such knowledge sharing behaviours (A1Alawi et al., 2007). When employees achieve an extrinsic or intrinsic reward for their knowledge sharing, they are motivated to share knowledge (Hau et al., 2013). Extrinsic and intrinsic rewards have been shown to encourage knowledge sharing behaviour of employees (Huang et al., 2008) in both public and private companies (Pee et al., 2010; Kim and Lee, 2006). Extrinsic and intrinsic rewards therefore may encourage online knowledge sharing (Taylor, 2006).Therefore, the following hypotheses are proposed: 
H2: Extrinsic rewards are positively related to online knowledge sharing behaviour in a) public companies and b) private companies.

H3: Intrinsic rewards are positively related to online knowledge sharing behaviour in a) public companies and b) private companies.

\section{The moderating effect of organisational innovation}

Organisational innovation is a multi-dimensional construct and refers to the implementation of new organisational methods (Camisón and Villar-López, 2014), such as product, process and management innovation. Product innovation focuses on the creation of new products/services (Gumusluoglu and Ilsev, 2009), whereas process and management innovations relate to an organisation's tendency to implement new processes or management methods to improve the operation or service for improved organisational performance (Liao et al., 2007). Organisational innovation is an important source of sustainable competitive advantage because it has the potential to substantially enhance firm performance by reducing production and transaction costs and thereby improving labour productivity (Ganter and Hecker, 2013; Scuotto et al., 2017).

Employees in innovative organisations are more likely to share knowledge to contribute to the improvement of organisational performance, as such environments require high levels of innovative activity. Employees with high self-efficacy are more likely to share their knowledge to apply their individual knowledge to an organisation's production activties(Diliello et al., 2011; Bresciani et al., 2018; Wang and Chen, 2020). Employees in innovative organisations are often motivated to showcase their knowledge self-efficacy for mobilising the creativeness of employees through knowledge sharing (Diliello et al., 2011; Gong et al., 2009; Tierney and Farmer, 2011; Wang et al., 2013; Lo et al., 2020). The key tenets of the self-efficacy theory further suggests that self-efficacy stems from an intrinsic belief that employees have the ability to contribute valuable knowledge to an organisation. This belief is often sensitised to a firm's contextual environment (Bandura, 1977). As such organisations with a high level of innovation activities and employees with high levels of high self-efficacy may perceive their role as critical in maintaining or improving their organisation's innovation activities.

Consequently, they tend to share more knowledge than others. Thus, organisations that are innovative, as measured on a continuum of high to low, regardless of their legal structure - 
public or private, the influence of knowledge self-efficacy on knowledge sharing is moderated by organisational innovation. Therefore, we propose the following hypothesis:

H4: Organisational innovation moderate the impact of self-efficacy on online knowledge sharing behaviour in a) public companies and b) private companies.

The impact of rewards on knowledge sharing is not consistent across several studies, thereby raising the prospects of other organisational factors at play in explaining the variance in results. Indeed, in highly innovative organisations, employees tend to perceive extrinsic and intrinsic rewards differently. Employees that are active in knowledge sharing tend to contribute to the organisations so they maintain or improve their innovation. Thus, the effect of extrinsic and intrinsic rewards on employees' online knowledge sharing behaviours may be moderated by organisational innovation. Marx and Faleiros Soares (2015) further emphasise that organisational innovativeness should be taken into consideration when designing reward systems because the effect of rewards on online knowledge sharing may vary. Employees who are motivated by extrinsic and/or intrinsic rewards often perceive that they will engage in online knowledge sharing behaviours because of a specific type of reward that they value more (Pee et al., 2010; Kim and Lee, 2006; Huang et al., 2008; Al-Alawi et al., 2007). However, in companies with high innovation, regardless of whether they belong to public or private sectors, employees may have a feeling of higher responsibility to contribute to a company's innovation. These employees are less inclined to believe that their online knowledge sharing behaviours are caused by the rewards an organisation offers.

H5: Organisational innovation moderates the impact of extrinsic rewards on online knowledge sharing behaviour in a) public companies and b) private companies.

H6: Organisational innovation moderates the impact of intrinsic rewards on online knowledge sharing behaviour in a) public companies and b) private companies.

\section{Research methods}

Sample

The sample in this study comprises of employees working in Vietnamese banking companies who had used online knowledge platforms in these organisations to share their knowledge for various activities. These banking companies were selected based on the suggestion of Kim and Lee (2006) and Tohidinia and Mosakhani (2010) because knowledge management practices 
are essential in this industry, especially as this industry has a well-developed information technology infrastructure for online knowledge sharing.

A total of 200 usable responses were received from an initial of 892, indicating the response rate of $22.4 \%$. Of the total sample, $40.5 \%$ were male, and $59.5 \%$ were female. The majority of respondents were in the age group of 21 to 30 years (58.5\%), followed by age groups of 31 40 years $(33 \%), 41-50$ years $(6 \%)$ and 51-60 years $(2.5 \%)$. In terms of their qualifications, more than $70 \%$ of respondents had a bachelor's degree and the nature of majority of respondents was working in full-time role. Online platform systems used in organisations for sharing knowledge include platforms, such as Skype, Zoom, Zalo, WhatsApp and Messenger.

\section{Measurement}

All measurement items were adapted from existing scales in the literature to ensure content validity, using a 7-point Likert scale, wherein, 1 for 'strongly disagree', and 7 for 'strongly agree'. Knowledge self-efficacy was measured by adapting knowledge self-efficacy scale used in the Bock et al. (2005) study to assess the confidence employees had in their ability to contribute to an organisation using online knowledge sharing, including items such as "When sharing knowledge online, I feel confident in my ability and knowledge to help my organisation to improve work processes". The Cronbach's alpha value for this adapted scale was 0.95 .

Extrinsic rewards were adapted from Lin (2007a), assessing the tangible incentives that employees of an organisation may receive for sharing their knowledge using online platforms with their colleagues, including items such as "I share my knowledge online because in return I will receive a higher bonus". The Cronbach's alpha value for this adapted scale is 0.91 . Intrinsic rewards were adapted from Choi et al. (2008), which assessed the intangible incentives that employees of an organisation may receive for sharing their knowledge sharing using online platforms with their colleagues, including items such as "The more I share my knowledge online, the more my reputation would be enhanced". The Cronbach's alpha value for this adapted scale was 0.96 . Knowledge sharing behaviour was measured by adapting the scale in Akhavan and Mahdi Hosseini (2016) and Kim and Lee (2013) to assess employees' online knowledge sharing behaviour, including items such as "I often share my information, skills and experiences with my colleagues". Cronbach's alpha value for this adapted scale is 0.93 .

Organisational innovation was measured by adapting the scale in the study of Liao et al. (2007). This scale comprises three dimensions (product, process and management innovation). Product innovation was assessed organisational capability to provide differentiated or new 
products or services, including items such as "Our company often develops new products and services well accepted by the market". Process innovation is referred to as an organisational capability that identifies a better or new manufacturing or service process to achieve better performance, including items such as "Our company always acquires new skills or equipment to improve the operation or service process". Management innovations relates to organisational capabilities to improve organisational performance by implementing new managerial practices, systems, and methods, such as innovating a firm's business model, including items such as “Our company's department heads often adopt new leadership approaches to lead all employees towards task completion".The reliabilities were .96 for all dimensions.

\section{Procedures}

The questionnaire was initiated based on the scales adapted from the previous studies. A pilot survey of 30 Vietnamese employees was conducted to check for the reliability of the measures and the clarity of the questionnaire. The main data collection process began with an email sent to employees in Vietnamese banking companies to invite employees who have engaged in online knowledge sharing in their companies, to participate in a survey using the online survey link in SurveyMonkey. SurveyMonkey was used in this study due to its ability to ensure data security and the anonymity of the participants at all times. Two funnelling questions were placed at the beginning of the online survey to ensure that the employees 1) worked in the banking industry; and 2) had used an online platform in their organisation to share knowledge. These filtering questions ensured that only eligible respondents participated in the survey. To minimise response bias, similar questions were placed in different sections of the survey to ensure identical responses. 200 completed questionnaires were received within three months of the launch of the survey.

\section{Results}

The measurement and structural models were evaluated by the component-based partial least squares (PLS) approach. Smart-PLS 3 software was employed for data analysis.

\section{Mesurement model}

In the measurement model, the internal consistency reliability of constructs was assessed using Cronbach's alpha and composite reliability tests (see Table 2). All the Cronbach's alpha values of the measures were above the acceptable threshold of 0.70 (Nunnally, 1994). The composite 
reliability of all constructs also surpassed the recommended level of 0.7 (Nunnally, 1994). The convergent validity was confirmed when all the average variance extracted (AVE) values was greater than 0.5, thereby exceeding the suggested threshold value (Fornell and Larcker (1981). The discriminant validity was confirmed when (see Table 3), as none of the construct correlations (non-diagonal entries) exceeded the corresponding square root of the AVE values (diagonal entries).

\section{Common method bias}

Both ex-ante and ex-post procedures were undertaken to minimize response bias and errors. Regarding the ex-ante procedure, validated scales from previous studies to measure the variables that were reported with high reliability were adapted. A pilot study was conducted to check for reliability. In the introduction section of the main survey, respondents were assured of anonymity in their responses. For the ex-post procedure, common method bias was assessed through variance inflation factor (VIF). In SmartPLS V3, a consistent PLS algorithm analysis was run with the weighting scheme at the factor level to check all inner VIF values. Consistent with PLS algorithm analysis, each of the five variables was considered in turn as a dependent variable; the others were considered as independent variables. The VIF scores of all constructs were well below the threshold of 3.3 recommended by Bharati et al. (2015), indicating that multicollinearity and common method bias were unlikely to be an issue with the data.

Table 2 Reliability

\begin{tabular}{|c|c|c|c|}
\hline Variable & Source & Measures & $\begin{array}{l}\text { Factor } \\
\text { loading }\end{array}$ \\
\hline \multirow[t]{6}{*}{$\begin{array}{l}\text { Knowledge self-efficacy } \\
(\alpha=.95, \mathrm{CR}=.95, \mathrm{AVE}=.80)\end{array}$} & $\begin{array}{l}\text { Bock et al. } \\
(2005)\end{array}$ & $\begin{array}{l}\text { When sharing knowledge online, I feel confident in my ability and } \\
\text { knowledge to.... }\end{array}$ & \\
\hline & & (1) help colleagues to solve their problems & .91 \\
\hline & & (2) create new business opportunities for my organisation & .89 \\
\hline & & (3) help my organisation to improve work processes & .90 \\
\hline & & (4) help my organisation to increase productivity & .83 \\
\hline & & $\begin{array}{l}\text { (5) help my organisation to achieve performance objectives and } \\
\text { outcomes }\end{array}$ & .94 \\
\hline \multirow[t]{4}{*}{$\begin{array}{l}\text { Extrinsic rewards } \\
(\alpha=.91, \mathrm{CR}=.91, \mathrm{AVE}=.72)\end{array}$} & $\operatorname{Lin}(2007 a)$ & $\begin{array}{l}\text { I share my knowledge online because in return I will receive... } \\
\text { (1) a higher salary }\end{array}$ & .77 \\
\hline & & (2) a higher bonus & .73 \\
\hline & & (3) increased promotion opportunities & .93 \\
\hline & & (4) increased job security & .93 \\
\hline \multirow{4}{*}{$\begin{array}{l}\text { Intrinsic rewards } \\
(\alpha=.96, \mathrm{CR}=.96, \mathrm{AVE}=.84)\end{array}$} & Choi et al. & (1) People honour my job when I teach or share my own skills online & .96 \\
\hline & $(2008)$ & $\begin{array}{l}\text { (2) The more I share my own knowledge online, the more my } \\
\text { reputation would be enhanced }\end{array}$ & .88 \\
\hline & & $\begin{array}{l}\text { (3) When I share my knowledge online, I can get more chance to } \\
\text { show my skills to the other colleagues }\end{array}$ & .87 \\
\hline & & $\begin{array}{l}\text { (4) When I share my knowledge online, people approve of me as an } \\
\text { expert in our company }\end{array}$ & .96 \\
\hline
\end{tabular}




\begin{tabular}{|c|c|c|c|}
\hline \multirow[t]{5}{*}{$\begin{array}{l}\text { Product innovation } \\
(\alpha=.96, \mathrm{CR}=.96, \mathrm{AVE}=.82)\end{array}$} & $\begin{array}{l}\text { Liao et al. } \\
(2007)\end{array}$ & $\begin{array}{l}\text { (1) Our company often develops new products and services well } \\
\text { accepted by the market }\end{array}$ & .88 \\
\hline & & $\begin{array}{l}\text { (2) Our company can often launch new products or services faster } \\
\text { than our competitors }\end{array}$ & .87 \\
\hline & & $\begin{array}{l}\text { (3) Our company is frequently the first to market new products and } \\
\text { services }\end{array}$ & .92 \\
\hline & & $\begin{array}{l}\text { (4) Our company has a better capacity in R\&D for new products and } \\
\text { services than our competitors }\end{array}$ & .94 \\
\hline & & (5) Our new product introduction has increased over the last 5 years & .91 \\
\hline \multirow[t]{4}{*}{$\begin{array}{l}\text { Process innovation } \\
(\alpha=.96, \mathrm{CR}=.96, \mathrm{AVE}=.82)\end{array}$} & $\begin{array}{l}\text { Liao et al. } \\
(2007)\end{array}$ & $\begin{array}{l}\text { (1) Our company always acquires new skills or equipment to improve } \\
\text { the operation or service process }\end{array}$ & .93 \\
\hline & & $\begin{array}{l}\text { (2) Our company can develop more efficient process and service } \\
\text { operation }\end{array}$ & .93 \\
\hline & & (3) Our company is creative in its operating methods & .94 \\
\hline & & (4) Our company seeks new ways of doing things & .92 \\
\hline \multirow[t]{4}{*}{$\begin{array}{l}\text { Management innovation } \\
(\alpha=.96, \mathrm{CR}=.97, \mathrm{AVE}=.88)\end{array}$} & $\begin{array}{l}\text { Liao et al. } \\
(2007)\end{array}$ & $\begin{array}{l}\text { (1) Our company's department heads often adopt new leadership } \\
\text { approaches to lead all employees towards task completion }\end{array}$ & .97 \\
\hline & & $\begin{array}{l}\text { (2) Our company emphasises innovative and creative capability when } \\
\text { recruiting a new employee }\end{array}$ & .94 \\
\hline & & $\begin{array}{l}\text { (3) Employees are often given incentives to generate new ideas as } \\
\text { well as seek new ways of doing things }\end{array}$ & .92 \\
\hline & & $\begin{array}{l}\text { (4) Our company will change the divisions of work among different } \\
\text { departments according to the needs of market management }\end{array}$ & .92 \\
\hline \multirow[t]{4}{*}{$\begin{array}{l}\text { Knowledge sharing behaviour } \\
(\alpha=.93, \mathrm{CR}=.93, \mathrm{AVE}=.76)\end{array}$} & $\begin{array}{l}\text { Akhavan } \\
\text { and Mahdi }\end{array}$ & $\begin{array}{l}\text { (1) I often share my information, skills and experiences with my } \\
\text { colleagues online }\end{array}$ & .92 \\
\hline & $\begin{array}{l}\text { Hosseini } \\
\text { (2016) and }\end{array}$ & $\begin{array}{l}\text { (2) When I have learned something new I often tell my colleagues } \\
\text { about it online }\end{array}$ & .89 \\
\hline & Kim and Lee & (3) I regularly tell my colleagues online what I am doing & .79 \\
\hline & $(2013)$ & $\begin{array}{l}\text { (4) Online knowledge sharing among my colleagues is considered } \\
\text { normal }\end{array}$ & .92 \\
\hline
\end{tabular}

A: Cronbach's alpha CR: composite reliability; AVE: average variance extracted

Table 3 Discriminant validity

\begin{tabular}{llllll}
\hline & 1 & 2 & 3 & 4 & 5 \\
\hline 1. Knowledge self-efficacy & .89 & & & & \\
2. Extrinsic rewards & $.44^{*}$ & .84 & & & \\
3. Intrinsic rewards & $.61 *$ & $.62 *$ & .92 & & \\
4. Organisational innovation & $.67 *$ & $.44 *$ & $.72 *$ & $\mathbf{. 8 8}$ & \\
5. Knowledge sharing behaviour & $.64 *$ & $.46^{*}$ & $.70 *$ & $.63 *$ & $\mathbf{. 8 8}$ \\
\hline
\end{tabular}

*Correlation is significant at the .01 level (2-tailed);

The bold numbers in the diagonal row are the square roots of AVE

\section{Structural model}

The structural model was assessed. The coefficient of determination $\left(\mathrm{R}^{2}\right)$ was $58.5 \%$, indicating that $58.5 \%$ of the variance in the level of online knowledge sharing behaviour can be explained by knowledge self-efficacy, extrinsic and intrinsic rewards.

In order to test the hypotheses, the sample was split into two groups: public and private companies. In PLS 3, a multi-group analysis with 1000 subsamples was run. H1a and H1b proposed that knowledge self-efficacy was significantly and positively related to online 
knowledge sharing behaviour in public and private companies. As shown in Table 4, knowledge self-efficacy had a significant positive effect on knowledge sharing behaviour in both subgroups (i.e. in public companies: $\beta=.43, p<.001$; private companies: $\beta=.38, p<.001$ ); thus, hypotheses $\mathrm{H} 1 \mathrm{a}$ and $\mathrm{H} 1 \mathrm{~b}$ were supported. The results in Table 4 also showed no different effects of self-efficacy on online knowledge sharing behaviour between groups of public and private sector firms.

Hypotheses $\mathrm{H} 2 \mathrm{a}, \mathrm{b}$ and $\mathrm{H} 3 \mathrm{a}, \mathrm{b}$ proposed that extrinsic rewards and intrinsic rewards were significantly and positively related to online knowledge sharing behaviour in public and private companies. The results showed that extrinsic rewards significantly affected knowledge sharing behaviour in private companies $\left(\beta_{\text {extrinsic rewards }}=.20, \mathrm{p}<.01\right)$ and intrinsic rewards significantly affected knowledge sharing behaviour in public companies $\left(\beta_{\text {intrinsic rewards }}=.52, \mathrm{p}<.001\right)$. In contrast, extrinsic rewards did not influence online knowledge sharing behaviour in public companies $\left(\beta_{\text {extrinsic rewards }}=-.08, \mathrm{p}>.05\right)$ and intrinsic rewards did not influence online knowledge sharing behaviour in private companies $\left(\beta_{\text {intrinsic rewards }}=.22, p>.05\right)$. Thus, hypotheses $\mathrm{H} 2 \mathrm{~b}$ and $\mathrm{H} 3 \mathrm{a}$, were supported, but $\mathrm{H} 2 \mathrm{a}$ and $\mathrm{H} 3 \mathrm{~b}$ were not supported. The differences in path coefficients of the impact of determinants of online knowledge sharing behaviour in two groups was further assessed.

Table 5 shows the moderating effect of organisational innovation on the impact of individual and organisational factors on online knowledge sharing behaviours. The results indicate that organisational innovation had a moderating effect in the relationship between extrinsic rewards and online knowledge sharing behaviour $(\beta=.32, \mathrm{p}<.01)$ and between intrinsic rewards and online knowledge sharing behaviour $(\beta=-.30, p<.01)$ in the private sector group of firms. Therefore, hypotheses H5b and H6b were supported, but hypotheses H4a, H4b, H5a, and H6a were not supported.

\section{Discussion}

Overall, the study highlights several key findings and contributes to the body of knowledge on knowledge sharing in general and online knowledge sharing, specifically. The findings of this study indicate that knowledge self-efficacy has a statistically significant influence on online knowledge sharing behaviour in both public and private companies. It is, therefore, recommended that by strengthening employees knowledge self-efficacy, we can motivate employees to share knowledge via online platforms. This finding is in line with the studies of Olatokun and Nwafor (2012), Hsu et al. (2007) and Lin (2007a). 
Interestingly, the results of this study show that extrinsic rewards were only effective in encouraging employees to share knowledge in private companies, whereas intrinsic rewards were only effective in public companies. This finding is in line with prior research by Buelens and Broeck (2007), Cacioppe and Mock (1984) and Crewson (1997), which shows that employees in private companies value extrinsic rewards more than those in public companies. In contrast, employees in public companies tend to be more motivated by intrinsic rewards (Leete, 2000). This finding is in line with the altruistic motivations that majority of public sector employees are driven with. Further, employees in public sector companies tend to be less inspired by material rewards and place more interest in the fairness and justice of the organisation than those in private companies (Lyons et al., 2006; Buelens and Broeck, 2007).

This proves that emphasis needs to be placed on extrinsic rewards in private companies, whereas more attention is needed on intrinsic rewards for employees in public companies. In private companies, the lure of extrinsic rewards such as salary, promotion and bonus is very strong in online knowledge sharing. It is worth noting that online knowledge sharing occurs only when employees in private companies perceive that extrinsic rewards exceed the costs of sharing knowledge online. Thus, the value of extrinsic rewards may be linked with specific performance with regard to online knowledge sharing (Bartol and Srivastava, 2002). On the other hand, in public companies, intrinsic rewards seem to be effective in motivating employees to share knowledge online. This is in accord with the findings of other researchers (Lyons et al., 2006; Buelens and Broeck, 2007) who argued that in comparison to private sector firms, employees in public companies are less motivated by extrinsic rewards, but place greater interest on intrinsic rewards such as fairness and justice in an organisation. 
Table 4: Structural Model Results

\begin{tabular}{|c|c|c|c|c|c|}
\hline \multirow[t]{2}{*}{ Path } & \multirow{2}{*}{$\begin{array}{c}\text { Public } \\
(n=105)\end{array}$} & \multirow{2}{*}{$\begin{array}{l}\text { Private } \\
(n=95)\end{array}$} & \multicolumn{3}{|c|}{ Public/Private } \\
\hline & & & $\begin{array}{c}\text { Coefficient } \\
\text { difference }\end{array}$ & t value & Sig. \\
\hline Self-efficacy $\rightarrow$ Knowledge sharing behavior & $.43 * * *$ & $.38 * * *$ & .06 & .46 & NA \\
\hline Extrinsic rewards $\rightarrow$ Knowledge sharing behavior & -.08 & $.20 *$ & .28 & 1.86 & NA \\
\hline Intrinsic rewards $\rightarrow$ Knowledge sharing behavior & $.52 * * *$ & .22 & .30 & 1.79 & NA \\
\hline
\end{tabular}

$* * * \mathrm{p}<0.001, * * \mathrm{p}<0.01, * \mathrm{p}<0.05$, NA: not significant

Table 5: Moderating Effects of Organisational Innovation

\begin{tabular}{|c|c|c|c|c|c|}
\hline \multirow{2}{*}{ Path } & \multirow{2}{*}{$\begin{array}{c}\text { Public } \\
(\mathrm{n}=105)\end{array}$} & \multirow{2}{*}{$\begin{array}{c}\text { Private } \\
(n=95)\end{array}$} & \multicolumn{3}{|c|}{ Public/Private } \\
\hline & & & $\begin{array}{l}\text { Coefficient } \\
\text { difference }\end{array}$ & t value & Sig \\
\hline Self-efficacy $\rightarrow$ Knowledge sharing behavior & $.33 * *$ & $.31 * *$ & .02 & .14 & NA \\
\hline Extrinsic rewards $\rightarrow$ Knowledge sharing behavior & -.02 & .19 & .21 & 1.27 & NA \\
\hline Intrinsic rewards $\rightarrow$ Knowledge sharing behavior & $.39 * * *$ & -.06 & .45 & 2.18 & $*$ \\
\hline Organisational innovation $\rightarrow$ Knowledge sharing behavior & $.23^{*}$ & .21 & .02 & .10 & NA \\
\hline Self-efficacy x Organisational innovation $\rightarrow$ Knowledge sharing behavior & -.19 & -.03 & .16 & .94 & NA \\
\hline Extrinsic rewards x Organisational innovation $\rightarrow$ Knowledge sharing behavior & .03 & $.32 * *$ & .29 & 1.59 & NA \\
\hline Intrinsic rewards x Organisational innovation $\rightarrow$ Knowledge sharing behavior & .06 & $-.30 * *$ & .36 & 2.31 & $*$ \\
\hline
\end{tabular}


Our findings contrast with those of Amayah (2013), who argued that the private or public nature of an organisation does not affect factors driving knowledge sharing. This would suggest that knowledge management practices, if successfully used in private companies, can also be applied in public companies. Our findings suggest that the driving factors of online knowledge sharing in different organisational types are different. One possible reason for the contradiction is the context of the research. This study focuses on online knowledge sharing in an organisation. There are some differences in the nature of public and private companies, which may lead to the differences in the behaviour of employees.

By examining the influence of two kinds of rewards in public and private companies, the results of this study may explain the inconsistent findings of previous studies. While numerous studies such as those by Hau et al. (2013) and Huang et al. (2008) found extrinsic rewards had a strong influence on knowledge sharing, extrinsic rewards were found to have no influence in the study by Bock and Kim (2002) and Olatokun and Nwafor (2012), wherein, they examined employees in public companies. One possible reason for the different findings is that they investigated extrinsic rewards but did not pay attention to the organisational type.

The distinctive contribution of this study lies in examining the moderating effects of organisational innovation in online knowledge sharing behaviours. This findings is novel and relevant as private sector firms that pursue innovation activities, organisational innovation moderates the impact of extrinsic and intrinsic rewards on online knowledge sharing behaviours. Further, organisational innovation accentuates the influence of extrinsic rewards, whereas, it negatively moderates the impact of intrinsic rewards on online knowledge sharing behaviour. One possible explanation is that in highly innovative private sector companies, employees are driven by extrinsic rewards, and as a consequence they engage in online knowledge sharing behaviours. Further, employees in highly innovative private companies are likely to perceive that their online knowledge sharing behaviour is a prime responsibility for them to contribute to the company; thus, they place the success of the company higher than their reputation.

\section{Implications}

This study has attempted to examine the antecedents of online knowledge sharing behaviour in Vietnamese banks to further the understanding of online knowledge sharing behaviour in different organisational types. The model, which consists of individual and organisational factors, has been established to investigate their influence on online knowledge sharing 
behaviour in public and private companies. The results of this study indicate some implications for research and practice as follows.

\section{Implications for Theory}

Our findings are consistent with the key tenets of Vroom's (1964) motivation theory, social congntive theory (Bandura, 1974) and previous studies on knowledge sharing, which highlight the importance of an individual's knowledge self-efficacy and organisational rewards on online knowledge sharing. Successful online knowledge sharing behaviour requires a high level of employee's knowledge self-efficacy. If employees are confident about their knowledge, they are likely to share that knowledge through online portals. Further, by examining extrinsic and intrinsic rewards in a single study that incorporates both public and private sector firms, this study has demonstrated sector level differences due to the goals and values of work and employees in these firms.

Another theoretical contribution comes in the form of the examination of organisational innovation as the moderator in both public and private sector firms in examining the relationship between motivators of online knowledge sharing behaviour. Our novel research design and empirical findings has implications for further research as we noted differentces in the moderating effects of organisational innovation on online knowledge sharing behaviour in public and private companies and its motivators. Such differences suggest further research is needed on various knowledge management processes to tease out other inter-sectoral and an organisation's innovativeness. The extant theories do not differentiate any sectoral and organisational innovation orientational differences between motivators and self-efficacy on online knowledge sharing behaviours

\section{Implications for Practice}

The findings of this study suggests key implications for practice. The study found that by strengthening knowledge self-efficacy we can increase online knowledge sharing behaviours of employees in both public and private companies. This finding implies that an organisation should strengthen knowledge self-efficacy to motivate employees to share knowledge online.

With regard to knowledge self-efficacy, if employees feel they have nothing of value to contribute to their company, they may be discouraged from sharing knowledge online even though they may be willing to share. Thus, managers may consider the provision of training to improve employees' self-efficacy (Pee and Lee, 2015). Job design is also essential in 
improving knowledge self-efficacy. Employees, who are allocated work appropriate to their ability and given more autonomy, often have a higher level of knowledge self-efficacy (Pee and Lee, 2015). Continuous practice, role modelling, and positive communication may be helpful to enhance knowledge self-efficacy (Bryant et al., 2005). Managers also need to provide clear and unambiguous feedback to enhance employees' knowledge self-efficacy (Parker, 1998). In the recruitment procedure of the company, managers should consider the candidates who have a keen interest in the position and have great intellectual capacity (Parker, 1998).

Reward systems should be designed specifically to organisational type and keeping in mind the extent of organisational innovation. In public companies, intrinsic rewards seem to be effective in encouraging employees' online knowledge sharing behaviour. Thus, praise and public recognition can be used to motivate employees in public companies to share knowledge online. Those who work in private companies tend to be more interested in extrinsic rewards, such as promotion, bonus or salary. Notably, in highly innovation private companies, extrinsic rewards seem crucial to encourage employees to share knowledge online. Therefore, managers may establish a rating system that evaluates useful knowledge shared. The rating systems will show employee contribution via sharing knowledge online.

\section{Implications for future research}

Future research that builds on the findings of this study and overcomes its limitation is recommended.We conceptualised online knowledge sharing behaviour as a single dimension construct. Furture research may consider different dimensions of online knowledge sharing behaviour by incorporating dimesions such as knowledge donating, collecting and hoarding. Such a nuanced understanding will be critical in further understanding online knowledge sharing behaviours in a different light. Additionally, future research can examine the differences in employees motivations to use different types of online sharing platforms and why that might be the case. Organisational type in this study refers to public and private organisations. A different classification of organisations is based on the size/the number of employees to form small, medium and large companies. It may be fruitful for future studies to examine the impact of motivators along with this classification.

This study focuses on knowledge self-efficacy as individual factors, and extrinsic and extrinsic rewards. Future studies may consider examining other motives such as perceived selfenjoyment, reciprocity or social interaction ties. Finally, the sample was collected from the 
banking industry in Vietnam. Future researchers may wish to investigate the model in different industries and different countries to provide a more robust test of the hypotheses.

\section{References}

Akhavan, P. and Mahdi Hosseini, S. (2016), "Social capital, knowledge sharing, and innovation capability: An empirical study of R\&D teams in Iran", Technology Analysis \& Strategic Management, Vol. 28 No. 1, pp. 96-113.

Al-Alawi, A.I., Al-Marzooqi, N.Y. and Mohammed, Y.F. (2007), "Organizational culture and knowledge sharing: Critical success factors", Journal of Knowledge Management, Vol. 11 No. 2, pp. 22-42.

Al-Busaidi, K.A., Olfman, L., Ryan, T. and Leroy, G. (2010), "Sharing knowledge to a knowledge management system: Examining the motivators and the benefits in an Omani organization", Journal of Organizational Knowledge Management, Vol. 2010 No. 25835, pp. 1-12.

Alam, S.S., Abdullah, Z., Ishak, N.A. and Zain, Z.M. (2009), "Assessing knowledge sharing behaviour among employees in SMEs: An empirical study", International Business Research, Vol. 2 No. 2, pp. 115-22.

Amayah, A.T. (2013), "Determinants of knowledge sharing in a public sector organization", Journal of Knowledge Management, Vol. 17 No. 3, pp. 454-71.

Argote, L. and Ingram, P. (2000), "Knowledge transfer: A basis for competitive advantage in firms", Organizational Behavior and Human Decision Processes, Vol. 82 No. 1, pp. 150-69.

Baird, L. and Henderson, J.C. (2001), The knowledge engine: how to create fast cycles of knowledge-to-performance and performance-to-knowledge, 1st ed., BK, San Francisco.

Bandura, A. (1977), "Self-efficacy; toward a unifying theory of behavioral change", Psychological Review, Vol. 84 No. 3, pp. 191-215.

Bandura, A. and Walters, R.H. (1977), "Social learning theory", General Learning Press, pp. $1-46$. 
Bartol, K.M. and Srivastava, A. (2002), "Encouraging knowledge sharing: The role of organizational reward systems", Journal of Leadership \& Organizational Studies, Vol. 9 No. 1, pp. 64-76.

Bharati, P., Zhang, W. and Chaudhury, A. (2015), "Better knowledge with social media? Exploring the roles of social capital and organizational knowledge management", Journal of Knowledge Management, Vol. 19 No. 3, pp. 456-75.

Bock, G.W. and Kim, Y.G. (2002), "Breaking the myths of rewards: An exploratory study of attitudes about knowledge sharing", Information Resources Management Journal, Vol. 15 No. 2, pp. 14-21.

Bock, G.W., Zmud, R.W., Kim, Y.G. and Lee, J.N. (2005), "Behavioral intention formation in knowledge sharing: Examining the roles of extrinsic motivators, socialpsychological forces, and organizational climate", MIS Quarterly, Vol. 9 No. 1, pp. 87-111.

Borges, R. (2013), "Tacit knowledge sharing between IT workers: The role of organizational culture, personality, and social environment", Management Research Review, Vol. 36 No. 1, pp. 89-108.

Bresciani, S., Ferraris, A. and Del Giudice, M. (2018), "The management of organizational ambidexterity through alliances in a new context of analysis: Internet of Things (IoT) smart city projects", Technological Forecasting and Social Change, Vol. 136, pp. 331-38.

Bryant, S.L., Forte, A. and Bruckman, A. (2005), "Becoming Wikipedian: transformation of participation in a collaborative online encyclopedia", paper presented at Proceedings of the 2005 international ACM SIGGROUP conference on Supporting group work.

Buelens, M. and Broeck, H.V.d. (2007), "An analysis of differences in work motivation between public and private sector organizations", Public Administration Review, Vol. 67 No. 1, pp. 65-74.

Bughin, J. and Manyika, J. (2007), "How businesses are using Web 2.0: A McKinsey global survey", McKinsey Quarterly Web Exclusive. McKinsey and Company.

Cacioppe, R. and Mock, P. (1984), "A Comparison of the quality of work experience in government and private organizations", Human relations, Vol. 37 No. 11, pp. 923-40.

Calantone, R.J., Cavusgil, S.T. and Zhao, Y. (2002), "Learning orientation, firm innovation capability, and firm performance", Industrial Marketing Management, Vol. 31 No. 6, pp. 515-24. 
Calantone, R.J. and Stanko, M.A. (2007), "Drivers of outsourced innovation: An exploratory study", Journal of Product Innovation Management, Vol. 24 No. 3, pp. 230-41.

Camisón, C. and Villar-López, A. (2014), "Organizational innovation as an enabler of technological innovation capabilities and firm performance", Journal of Business Research, Vol. 67 No. 1, pp. 2891-902.

Cho, N., zheng Li, G. and Su, C.J. (2007), "An empirical study on the effect of individual factors on knowledge sharing by knowledge type", Journal of Global Business and Technology, Vol. 3 No. 2, pp. 1-15.

Choi, S.Y., Kang, Y.S. and Lee, H. (2008), "The effects of socio-technical enablers on knowledge sharing: An exploratory examination", Journal of Information Science, Vol. 34 No. 5, pp. 1-13.

Cohen, W.M. and Levinthal, D.A. (1990), "Absorptive capacity: A new perspective on learning and innovation", Administrative Science Quarterly, pp. 128-52.

Crewson, P.E. (1997), "Public-service motivation: Building empirical evidence of incidence and effect", Journal of public administration research and theory, Vol. 7 No. 4, pp. 499-518.

Davenport, T.H. and Prusak, L. (1997), Information ecology: Mastering the information and knowledge environment, Oxford University Press on Demand.

Diliello, T.C., Houghton, J.D. and Dawley, D. (2011), "Narrowing the creativity gap: The moderating effects of perceived support for creativity", The Journal of Psychology, Vol. 145 No. 3, pp. 151-72.

Dong, G., Gia Liem, C. and Grossman, M. (2010), "Knowledge-sharing intention in Vietnamese organizations", VINE Journal of Information and Knowledge Management Systems, Vol. 40 No. 3/4, pp. 262-76.

Durmusoglu, S., Jacobs, M., Zamantili Nayir, D., Khilji, S. and Wang, X. (2014), "The quasimoderating role of organizational culture in the relationship between rewards and knowledge shared and gained", Journal of Knowledge Management, Vol. 18 No. 1, pp. 19-37.

Eze, U.C., Goh, G.G.G., Goh, C.Y. and Tan, T.L. (2013), "Perspectives of SMEs on knowledge sharing", VINE Journal of Information and Knowledge Management Systems, Vol. 43 No. 2, pp. 210-36. 
Fathi, N.M., Eze, U.C. and Goh, G.G.G. (2011), "Key determinants of knowledge sharing in an electronics manufacturing firm in Malaysia", Library Review, Vol. 60 No. 1, pp. 53-67.

Fornell, C. and Larcker, D.F. (1981), "Evaluating structural equation models with unobservable variables and measurement error", Journal of Marketing Research, Vol. 18 No. 1, pp. 39-50.

Ganter, A. and Hecker, A. (2013), "Deciphering antecedents of organizational innovation", Journal of Business Research, Vol. 66 No. 5, pp. 575-84.

Gebreegziabher, A.T. (2014), "Enhancing knowledge sharing: Case of Nile Basin Initiative (NBI)", International Journal of Innovation and Applied Studies, Vol. 8 No. 3, pp. 1015-80.

Gong, Y., Huang, J.-c. and Farh, J.-1. (2009), "Employee learning orientation, transformational leadership, and employee creativity: The mediating role of employee creative self-efficacy", Academy of Management Journal, Vol. 52 No. 4, pp. 765-78.

Gumusluoglu, L. and Ilsev, A. (2009), "Transformational leadership, creativity, and organizational innovation", Journal of Business Research, Vol. 62 No. 4, pp. 461-73.

Hau, Y.S., Kim, B., Lee, H. and Kim, Y.G. (2013), "The effects of individual motivations and social capital on employee's tacit and explicit knowledge sharing intentions", International Journal of Information Management, Vol. 33, pp. 356-66.

Heffron, F.A. (1989), Organization theory and public organizations: the political connection, Prentice Hall, Englewood Cliffs, N.J.

Hsu, M.H., Ju, T.L., Yen, C.H. and Chang, C.M. (2007), "Knowledge sharing behavior in virtual communities: The relationship between trust, self-efficacy, and outcome expectations", International Journal of Human-Computer Studies, Vol. 65 No. 2, pp. 153-69.

Huang, Q., Davison, R.M. and Gu, J. (2008), "Impact of personal and cultural factors on knowledge sharing in China", Asia Pacific Journal of Management, Vol. 25 No. 3, pp. 451-71.

Hung, S.Y., Durcikova, A., Lai, H.M. and Lin, W.M. (2011), "The influence of intrinsic and extrinsic motivation on individuals' knowledge sharing behavior", International Journal of Human-Computer Studies, Vol. 69 No. 6, pp. 415-27. 
Kankanhalli, A., Bernard, C.Y.T. and Wei, K.-K. (2005a), "Contributing knowledge to electronic knowledge repositories: An empirical investigation", MIS Quarterly, Vol. 29 No. 1, pp. 113-43.

Kankanhalli, A., Tan, B.C. and Wei, K.K. (2005b), "Contributing knowledge to electronic knowledge repositories: an empirical investigation", MIS Quarterly, pp. 113-43.

Khedhaouria, A. and Jamal, A. (2015), "Sourcing knowledge for innovation: Knowledge reuse and creation in project teams", Journal of Knowledge Management, Vol. 19 No. 5, pp. 932-48.

Kiatkawsin, K. and Han, H. (2017), "Young travelers' intention to behave proenvironmentally: Merging the value-belief-norm theory and the expectancy theory", Tourism management, Vol. 59, pp. 76-88.

Kim, S. and Lee, H. (2006), "The impact of organizational context and information technology on employee knowledge-sharing capabilities", Public Administration Review, Vol. 66 No. 3, pp. 370-85.

Kim, T.T. and Lee, G. (2013), "Hospitality employee knowledge-sharing behaviors in the relationship between goal orientations and service innovative behavior", International Journal of Hospitality Management, Vol. 34, pp. 324-37.

Kogut, B. and Zander, U. (1992), "Knowledge of the firm, combinative capabilities, and the replication of technology", Organization Science, Vol. 3 No. 3, pp. 383-97.

Kumar, K., Bakhshi, A. and Rani, E. (2009), "Linking the big five personality domains to organizational citizenship behavior", International Journal of Psychological Studies, Vol. 1 No. 2, pp. 73.

Kumar, N. and Rose, R.C. (2012), "The impact of knowledge sharing and Islamic work ethic on innovation capability", Cross Cultural Management: An International Journal, Vol. 19 No. 2, pp. 142-65.

Leete, L. (2000), "Wage equity and employee motivation in nonprofit and for-profit organizations", Journal of Economic Behavior and Organization, Vol. 43 No. 4, pp. 423-46.

Liao, L.F. (2008), "Knowledge-sharing in R\&D departments: A social power and social exchange theory perspective", The International Journal of Human Resource Management, Vol. 19 No. 10, pp. 1881-95. 
Liao, S.-h., Fei, W.-C. and Chen, C.-C. (2007), "Knowledge sharing, absorptive capacity, and innovation capability: An empirical study of Taiwan's knowledge-intensive industries", Journal of Information Science, Vol. 33 No. 3, pp. 340-59.

Liebowitz, J. and Yan, C. (2004), "Knowledge sharing proficiencies: The key to knowledge management", in Holsapple, C.W. (Ed.) Handbook on Knowledge Management 1: Knowledge Matters, Springer, Verlag, Berlin, pp. 409-24.

Lin, H.F. (2007a), "Effects of extrinsic and intrinsic motivation on employee knowledge sharing intentions", Journal of Information Science, Vol. 33 No. 2, pp. 135-49.

Lin, H.F. (2007b), "Knowledge sharing and firm innovation capability: An empirical study", International Journal of manpower, Vol. 28 No. 3/4, pp. 315-32.

Lin, H.F., Lee, H.S. and Wang, D.W. (2009), "Evaluation of factors influencing knowledge sharing based on a fuzzy AHP approach", Journal of Information Science, Vol. 35 No. 1, pp. 25-44.

Lin, S.W. and Lo, L.Y.S. (2015), "Mechanisms to motivate knowledge sharing: integrating the reward systems and social network perspectives", Journal of Knowledge Management, Vol. 19 No. 2, pp. 212-35.

Lo, J.Y., Nag, R., Xu, L. and Agung, S.D. (2020), "Organizational innovation efforts in multiple emerging market categories: Exploring the interplay of opportunity, ambiguity, and socio-cognitive contexts", Research Policy, Vol. 49 No. 3, pp. 103911.

Lyons, S.T., Duxbury, L.E. and Higgins, C.A. (2006), "A comparison of the values and commitment of private sector, public sector, and parapublic sector employees", Public Administration Review, Vol. 66 No. 4, pp. 605-18.

Malik, A. (2018). Strategic Human Resource Management and Employment Relations. Singapore: Springer Publishing.

Malik, A., Boyle, B., \& Mitchell, R. (2017), "Contextual ambidexterity and innovation in healthcare in India: the role of HRM", Personnel Review, Vol. 46 No. 7, pp. 13581380 .

Malik, A., Pereira, V., \& Budhwar, P. (2018). Value creation and capture through human resource management practices: Gazing through the business model lens. Organizational Dynamics, Vol. 47 No. 3, pp. 180-88.

Malik, A., Froese, F. J., \& Sharma, P. (2020), "Role of HRM in knowledge integration: Towards a conceptual framework", Journal of Business Research, Vol. 109, pp. 524535. 
Malik, A., \& Nilakant, V. (2016), "Knowledge integration mechanisms in high-technology business-to-business services vendors", Knowledge Management Research \& Practice, Vol. 14 No. 4, pp. 565-574.

Marx, R. and Faleiros Soares, J.P. (2015), "Organizational context variables to be considered in the design of rewards system oriented to product innovation", in Portland International Conference on Management of Engineering and Technology (PICMET), Portland, 2015, Portland International Conference on Management, pp. 1641-56.

Milner, E.M. (2000), Managing information and knowledge in the public sector, Routledge, London.

Nguyen, T.-M. (2020a), "Do extrinsic motivation and organisational culture additively strengthen intrinsic motivation in online knowledge sharing?: An empirical study", VINE Journal of Information and Knowledge Management Systems, Vol. 50 No. 1, pp. 75-93.

Nguyen, T.-M. (2020b), "Four-dimensional model: A literature review in online organisational knowledge sharing ", VINE Journal of Information and Knowledge Management Systems, Vol. forthcoming.

Nguyen, T.-M., Dinh, V.T. and Nham, P.T. (2019a), "Online knowledge sharing in Vietnamese tele-communication companies: An integration of social psychology models", Knowledge Management \& E-Learning, Vol. 11 No. 4, pp. 497-521.

Nguyen, T.-M., Nham, P.T. and Hoang, V.-N. (2019b), "The theory of planned behavior and knowledge sharing: A systematic review and meta-analytic structural equation modelling", VINE Journal of Information and Knowledge Management Systems, Vol. 49 No. 1, pp. 76-94.

Nguyen, T.-M., Nham, T.P., Froese, F.J. and Malik, A. (2019c), "Motivation and knowledge sharing: a meta-analysis of main and moderating effects", Journal of Knowledge Management, Vol. 23 No. 5, pp. 998-1016.

Nunnally, J.C. (1994), Psychometric theory (3rd ed.), 3rd ed., McGraw-Hill, New York.

Olatokun, W. and Nwafor, C.I. (2012), "The effect of extrinsic and intrinsic motivation on knowledge sharing intentions of civil servants in Ebonyi State, Nigeria", Information Development, Vol. 28 No. 3, pp. 216-34.

Pandey, S.K. and Wright, B.E. (2006), "Connecting the dots in public management: Political environment, organizational goal ambiguity, and the public manager's role ambiguity", Journal of public administration research and theory, Vol. 16 No. 4, pp. 511-32. 
Panopto. (2018), "Panopto workplace knowledge and productivity report", in.

Parker, S.K. (1998), "Enhancing role breadth self-efficacy: The roles of job enrichment and other organizational interventions", Journal of Applied Psychology, Vol. 83 No. 6, pp. $835-52$.

Pee, L. and Lee, J. (2015), "Intrinsically motivating employees' online knowledge sharing: Understanding the effects of job design", International Journal of Information Management, Vol. 35 No. 6, pp. 679-90.

Pee, L.G., Kankanhalli, A. and Kim, H.W. (2010), "Knowledge sharing in information systems development: A social interdependence perspective", Journal of the Association for Information Systems, Vol. 11 No. 10, pp. 550-75.

Purvis, R.L., Zagenczyk, T.J. and McCray, G.E. (2015), "What's in it for me? Using expectancy theory and climate to explain stakeholder participation, its direction and intensity", International Journal of Project Management, Vol. 33 No. 1, pp. 3-14.

Roca, J.C. and Gagné, M. (2008), "Understanding e-learning continuance intention in the workplace: A self-determination theory perspective", Computers in Human Behavior, Vol. 24 No. 4, pp. 1585-604.

Ruggles, R. (1998), "The state of the notion: Knowledge management in practice", California management review, Vol. 40 No. 3, pp. 80-89.

Ryan, R.M. and Deci, E.L. (2000), "Intrinsic and extrinsic motivations: Classic definitions and new directions", Contemporary educational psychology, Vol. 25 No. 1, pp. 54-67.

Scarbrough, H. (2003), "Knowledge management, HRM and the innovation process", International Journal of manpower, Vol. 24 No. 5, pp. 501-16.

Scuotto, V., Santoro, G., Bresciani, S. and Del Giudice, M. (2017), "Shifting intra- and interorganizational innovation processes towards digital business: An empirical analysis of SMEs", Creativity and Innovation Management, Vol. 26 No. 3, pp. 247-55.

Seba, I., Rowley, J. and Delbridge, R. (2012a), "Knowledge sharing in the Dubai police force", Journal of Knowledge Management, Vol. 16 No. 1, pp. 114-28.

Seba, I., Rowley, J. and Lambert, S. (2012b), "Factors affecting attitudes and intentions towards knowledge sharing in the Dubai Police Force", International Journal of Information Management, Vol. 32 No. 4, pp. 372-80. 
Spreitzer, G.M. (1995), "Psychological empowerment in the workplace: Dimensions, measurement, and validation", Academy of Management Journal, Vol. 38 No. 5, pp. 1442-65.

Tan, C.N.L. (2016), "Enhancing knowledge sharing and research collaboration among academics: The role of knowledge management", Higher Education, Vol. 71 No. 4 , pp. 525-56.

Tangaraja, G., Mohd Rasdi, R., Ismail, M. and Abu Samah, B. (2015), "Fostering knowledge sharing behaviour among public sector managers: a proposed model for the Malaysian public service", Journal of Knowledge Management, Vol. 19 No. 1, pp. 121-40.

Taylor, E.Z. (2006), "The effect of incentives on knowledge sharing in computer-mediated communication: An experimental investigation", Journal of Information Systems, Vol. 20 No. 1, pp. 103-16.

Tierney, P. and Farmer, S.M. (2011), "Creative self-efficacy development and creative performance over time", Journal of Applied Psychology, Vol. 96 No. 2, pp. 277-93.

Tohidinia, Z. and Mosakhani, M. (2010), "Knowledge sharing behaviour and its predictors", Industrial Management \& Data Systems, Vol. 110 No. 4, pp. 611-31.

Van den Hooff, B., Schouten, A.P. and Simonovski, S. (2012), "What one feels and what one knows: the influence of emotions on attitudes and intentions towards knowledge sharing", Journal of Knowledge Management, Vol. 16 No. 1, pp. 148-58.

Wang, C.-C. and Yang, Y.-J. (2007), "Personality and intention to share knowledge: An empirical study of scientists in and RD laboratory", Social Behavior and Personality, Vol. 35 No. 10, pp. 1427-36.

Wang, F. and Chen, K. (2020), "Do product imitation and innovation require different patterns of organizational innovation? Evidence from Chinese firms", Journal of Business Research, Vol. 106, pp. 60-74.

Wang, P., Rode, J.C., Shi, K., Luo, Z. and Chen, W. (2013), "A workgroup climate perspective on the relationships among transformational leadership, workgroup diversity, and employee creativity", Group \& Organization Management, Vol. 38 No. 3, pp. 334-60.

Wasko, M.M. and Faraj, S. (2005), "Why should I share? Examining social capital and knowledge contribution in electronic networks of practice", MIS Quarterly, Vol. 29 No. 1, pp. 35-57. 
Wickramasinghe, V. and Widyaratne, R. (2012), "Effects of interpersonal trust, team leader support, rewards, and knowledge sharing mechanisms on knowledge sharing in project teams", VINE Journal of Information and Knowledge Management Systems, Vol. 42 No. 2, pp. 214-36.

Willem, A. and Buelens, M. (2007), "Knowledge sharing in public sector organizations: The effect of organizational characteristics on interdepartmental knowledge sharing", Journal of public administration research and theory, Vol. 17 No. 4, pp. 581-606.

Wu, Y. and Zhu, W. (2012), "An integrated theoretical model for determinants of knowledge sharing behaviours", Kybernetes, Vol. 41 No. 10, pp. 1462-82.

Yeh, W.-Y., Yeh, C.-Y. and Chen, C.-J. (2018), "Exploring the public-private and company size differences in employees' work characteristics and burnout: data analysis of a nationwide survey in Taiwan", Industrial Health, Vol. 56 No. 5, pp. 452-63.

Young, O., Brown, E., Keitt, T., Owyang, J., Koplowitz, R. and Lo, H. (2008), "Global enterprise Web 2.0 market forecast: 2007 to 2013", Forrester Research.

Zhang, X., de Pablos, P.O. and Xu, Q. (2014), "Culture effects on the knowledge sharing in multi-national virtual classes: A mixed method", Computers in Human Behavior, Vol. 31 No. Supplement C, pp. 491-98.

Zhang, X., Pablos, P.O.d. and Zhou, Z. (2013), "Effect of knowledge sharing visibility on incentive-based relationship in Electronic Knowledge Management Systems: An empirical investigation", Computers in Human Behavior, Vol. 29 No. 2, pp. 307-13. 